\title{
Basement Membrane Thickness, Insulin Antibodies and HLA-Antigens in Long Standing Insulin Dependent Diabetics with and without Severe Retinopathy
}

\author{
T. Deckert ${ }^{1}$, J. Egeberg ${ }^{2}$, C. Frimodt-Møller ${ }^{3}$, E. Sander ${ }^{1}$, and A. Svejgaard ${ }^{4}$ \\ ${ }^{1}$ Steno Memorial Hospital, Gentofte, ${ }^{2}$ Institute of Anatomy, University of Copenhagen, ${ }^{3}$ Department of Urology, \\ and ${ }^{4}$ Tissue Typing Laboratory, University Hospital, Rigshospitalet, Copenhagen, Denmark
}

Summary. The study was designed to show whether there was any relation between muscle capillary basement membrane thickness, HLA-antigens, antiinsulin antibodies and proliferative retinopathy. Electron microscopic measurements of muscle capillary basement membrane thickness were performed on muscle biopsies from 15 insulin-dependent diabetics with severe proliferative retinopathy, 24 insulindependent diabetics with minimal retinopathy and 18 age- and sex matched non-diabetics. All the patients had had diabetes for 20 years or more. None had biochemical or clinical evidence of diabetic nephropathy. Basement membrane thickness was measured according to the methods of Siperstein and Williamson. Muscle capillary basement membrane thickening occurred in 32 of 39 diabetics, using the Siperstein method, but patients with proliferative retinopathy did not exhibit thicker basement membranes than patients with no or minimal changes in the retina. There were apparrent differences in HLA-antigens between diabetics with and without proliferative retinopathy, but they did not reach statistical significance. There was no correlation between muscle capillary basement membrane thickness and the quantity of insulin antibodies. The results indicate that factors other than basement membrane thickening and genetic factors in the HLA-region, are responsible for the development of proliferative retinopathy.

Key words: HLA-antigen, muscle capillary basal membrane thickness, insulin-antibodies, insulin dependent diabetes mellitus, retinopathy, proliferative retinopathy.
In general capillary basement membranes are thicker in diabetics than in non-diabetics of the same age [1]. In the kidney the glomerular capillary basement membranes are normal at the onset of diabetes mellitus, but show thickening already after 2-3 years [2]. As the number of vascular diabetic complications increases with the duration of the disease it has been postulated that the capillary basement membrane thickening could be "a useful index, perhaps the best available for monitoring deleterious effects of the diabetic state on the vascular system" [1]. Histological examinations of kidney biopsies however, have failed to prove any correlation of basement membrane thickness with clinical findings [3], and prognostic significance has been negligible [4].

In order to elucidate further, whether thickness of capillary basement membranes bears any relation to grosser organ changes, we have investigated the thicknesses of muscle capillary basement membranes in two groups of insulin-dependent diabetics with a duration of the disease of more than 20 years. In one group the patients suffered from severe retinopathy while the patients in the other group had no or minimal retinal changes. In addition an attempt was also made to determine whether the amount of insulin antibodies and/or genetic factors expressed in the HLA-antigens could be of pathogenetic significance for the development of retinopathy.

\section{Methods}

\section{Subjects}

Eighteen non-diabetics (11 males and 7 females) with no known disease and with no family history of diabetes (random blood glucose concentration $<5.4 \mathrm{mmol} / \mathrm{l}$ ) and 39 insulin-dependent diabetics (22 males and 17 females) were studied. Among the diabetics 24 (15 males and 9 females) had no significant retinopathy (2 
Table 1. Clinical details and basement membrane thickness in controls. Individual data including muscle capillary basement membrane thickness of 18 non-diabetics measured with Siperstein's (a) and Williamson's (b) procedure

\begin{tabular}{|c|c|c|c|c|c|c|c|}
\hline \multirow[t]{2}{*}{ No. } & \multirow[t]{2}{*}{ Sex } & \multirow[t]{2}{*}{$\begin{array}{l}\text { Age } \\
\text { (years) }\end{array}$} & \multirow[t]{2}{*}{$\begin{array}{l}\% \text { ideal } \\
\text { body weight }\end{array}$} & \multicolumn{2}{|c|}{ Blood pressure $\mathrm{mmHg}$} & \multicolumn{2}{|c|}{$\frac{\text { Basement membrane thickness }}{\text { mean } \pm \mathrm{SD}(\mathrm{nm})}$} \\
\hline & & & & & & (a) & (b) \\
\hline 1 & $0^{x}$ & 34 & 92 & 125 & 75 & $197 \pm 15$ & $109 \pm 6$ \\
\hline 2 & $0^{\pi}$ & 58 & 120 & 150 & 95 & $195 \pm 14$ & $126 \pm 11$ \\
\hline 3 & $0^{x}$ & 39 & 96 & 135 & 80 & $195 \pm 14$ & $118 \pm 7$ \\
\hline 4 & 0 & 43 & 103 & 115 & 65 & $119 \pm 5$ & $71 \pm 3$ \\
\hline 5 & $\sigma^{\pi}$ & 46 & 102 & 125 & 80 & $116 \pm 11$ & $73 \pm 8$ \\
\hline 6 & $\sigma^{2}$ & 59 & 110 & 160 & 90 & $138 \pm 6$ & $85 \pm 4$ \\
\hline 7 & $0^{\pi}$ & 54 & 113 & 150 & 95 & $173 \pm 8$ & $104 \pm 4$ \\
\hline 8 & $0^{\pi}$ & 40 & 96 & 135 & 90 & $243 \pm 13$ & $130 \pm 8$ \\
\hline 9 & $\sigma^{\pi}$ & 46 & 110 & 145 & 95 & $163 \pm 8$ & $101 \pm 5$ \\
\hline 10 & $0^{2}$ & 45 & 115 & 145 & 90 & $143 \pm 10$ & $85 \pm 6$ \\
\hline 11 & $0^{x}$ & 42 & 94 & 120 & 70 & $147 \pm 7$ & $90 \pm 4$ \\
\hline 12 & 웅 & 30 & 90 & 105 & 60 & $144 \pm 27$ & $100 \pm 23$ \\
\hline 13 & 9 & 46 & 100 & 145 & 90 & $189 \pm 21$ & $115 \pm 10$ \\
\hline 14 & 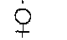 & 54 & 98 & 140 & 80 & $150 \pm 12$ & $89 \pm 6$ \\
\hline 15 & 9 & 47 & 94 & 135 & 90 & $183 \pm 20$ & $115 \pm 11$ \\
\hline 16 & $q$ & 42 & 105 & 145 & 90 & $152 \pm 9$ & $92 \pm 7$ \\
\hline 17 & $q$ & 51 & 103 & 150 & 90 & $121 \pm 5$ & $79 \pm 4$ \\
\hline 18 & $q$ & 51 & 85 & 105 & 65 & $174 \pm 16$ & $103 \pm 5$ \\
\hline Mean & & 46 & 101 & 135 & 83 & $163 \quad 12$ & 99 \\
\hline $\pm S E M$ & & 1.8 & 2.2 & 3.8 & 2.7 & $\begin{array}{ll}7.8 & 1.4\end{array}$ & 4.1 \\
\hline
\end{tabular}

microaneurysms or less per retina), 15 ( 7 males and 8 females) had severe proliferative retinopathy. Eight of this group were blind in both eyes and 4 blind in one eye. All diabetics were seen regularly at the out-patient clinic.

To participate in the investigation both non-diabetics and diabetics had to fulfill the following criteria: body weight within $80-120 \%$ of the ideal body weight according to Natvig's table [5]; systolic blood pressure $\leqslant 160 \mathrm{mmHg}$ and diastolic blood pressure $\leqslant 95 \mathrm{mmHg}$; tobacco consumption not exeeding 20 cigarettes daily; alcohol consumption below $25 \mathrm{~g}$ daily; oral contraceptives not used. In addition the following criteria were specified for the diabetics: onset of the disease before the age of 35; duration of diabetes of 20 years or more; regular visits to the diabetic centre; no diabetic nephropathy determined by several negative Albustix ${ }^{\circledR}$ tests and serum creatinine within the normal range $(66-133 \mu \mathrm{mol} / 1$ in males and 55-124 $\mu \mathrm{mol} / 1$ in females). In both groups of diabetics the erythrocyte sedimentation rate (ESR) was below $25 \mathrm{~mm} / \mathrm{h}$ except in one case where it was $29 \mathrm{~mm} / \mathrm{h}$. Ten of the 40 diabetics smoked 10-20 cigarettes/day. Of the ten heavy smokers three had proliferative retinopathy, seven had no or only minimal changes. Of the 25 non-cigarette smokers, ten had proliferative retinopathy, 15 had no or only minimal changes.

Before 1968 patients were treated with mixtures of ox and pig insulin. From 1968 only pig insulin was used, and during the last six months before investigation all patients received highly purified pig insulin (Insulin Leo Retard $\mathrm{RI}^{(3)}$ ). The goodness of diabetic control during the diabetic years could not be quantitated accurately, but the records did not reveal any systemic differencies in the two groups of diabetics. None of the controls but 4 of the patients were taking drugs in usual therapeutic doses: hydroflumethiazide (1), oxazepam (1), diazepam (1), and phenemalphenytoin (1). Informed consent was obtained from all patients and controls after careful explanation of the nature and purpose of the investigations.

\section{Analytical Methods}

Haemoglobin (Hb), ESR, ECG, blood pressure, serum creatinine, serum cholesterol and serum albumin were determined by standard laboratory procedures. Insulin antibodies were determined according to Andersen et al. [6]. With this technique the antibodies are measured as the insulin-binding capacity of the plasma. In normal non-diabetic individuals the insulin-binding capacity of plasma was below $15 \mu \mathrm{U} / \mathrm{ml}$. Insulin antibodies were determined in the plasma from 39 of the diabetics.

Tissue typing was performed in 37 of the diabetics according to Kissmeyer \& Kjerbye [7], and the distribution of the tissue types was compared with a control group of 1967 individuals collected among the Danish population [8].

Muscle biopsies were carried out in all 57 individuals. In one diabetic patient measurement by the method of Williamson could not be done for technical reasons. Biopsies were taken under local subcutaneous anaesthesia (lidocain, $1 \%$ ) with a punch biopsy needle, from the middle part of the lateral vastus muscle at a depth of $3 \mathrm{~cm}$. The pieces of muscle were immediately fixed in $1 \%$ ice-cold osmium tetroxide solution in veronal acetate buffer 450 nosm $/ \mathrm{kg}$ $\mathrm{pH} 7.3$, dehydrated in a graded series of alcohol and embedded in epon 812. Ultrathin sections were cut with a LKB Ultrotome III, stained with uranyl acetate and lead citrate and examined in a Phillips EM 300 electron microscope at $60 \mathrm{kV}$. The magnification calibration of the instrument was checked daily by means of a grating replica with 28.800 lines per inch (Enest F. Fullham cat. no. 1000). Cross sectioned capillaries were photographed at an initial magnification of approximately $2000 \mathrm{X}$ on $35 \mathrm{~mm}$ film and enlarged 10 times for subsequent measurements. The muscular capillary basement membrane thickness was measured with an accuracy of $0.1 \mathrm{~mm}$. In each individual 20 vessels were measured and the mean basement membrane thickness was estimated according to two different procedures. In one procedure 
Table 2. Clinical details and basement membrane thickness in diabetics with proliferative retinopathy. Individual data including muscle capillary basement membrane thickness measured with Siperstein's (a) and Williamson's (b) procedure, insulin-binding capacity of insulin antibodies (IBC) and HLA antigens on A, B and C locuses in 15 insulin-dependent diabetics with severe proliferative retinopathy

\begin{tabular}{|c|c|c|c|c|c|c|c|c|c|c|c|c|c|}
\hline \multirow[t]{2}{*}{ No. } & \multirow[t]{2}{*}{ Sex } & \multirow[t]{2}{*}{$\begin{array}{l}\text { Age } \\
\text { (years) }\end{array}$} & \multirow{2}{*}{$\begin{array}{l}\text { Dura- } \\
\text { tion } \\
\text { of dia- } \\
\text { betes } \\
\text { (years) }\end{array}$} & \multirow{2}{*}{$\begin{array}{l}\% \\
\text { ideal } \\
\text { body } \\
\text { weight }\end{array}$} & \multicolumn{2}{|c|}{$\begin{array}{l}\text { Blood pressure } \\
\mathrm{mmHg}\end{array}$} & \multirow{2}{*}{$\begin{array}{l}\text { Ins. } \\
\text { req. } \\
(\mathrm{U} / \mathrm{kg})\end{array}$} & \multicolumn{2}{|c|}{$\begin{array}{l}\text { Basement mem- } \\
\text { brane thickness } \\
\text { mean } \pm \mathrm{SD}(\mathrm{nm})\end{array}$} & \multirow[t]{2}{*}{$\begin{array}{l}\mathrm{IBC} \\
(\mu \mathrm{U} / \mathrm{ml})\end{array}$} & \multicolumn{3}{|l|}{ HLA - type } \\
\hline & & & & & systolic & diastolic & & (a) & (b) & & A & $\mathrm{B}$ & $\mathrm{C}$ \\
\hline 1 & $\sigma^{7}$ & 29 & 20 & 85 & 140 & 70 & 1.15 & $258 \pm 20$ & $133 \pm 12$ & 3 & 1,11 & 5,27 & w3 \\
\hline 2 & $\sigma^{7}$ & 58 & 24 & 120 & 150 & 95 & 0.27 & $150 \pm 9$ & $91 \pm 5$ & 9 & 2,28 & $12, \mathrm{w} 15$ & w3 \\
\hline 3 & $\sigma^{T}$ & 40 & 26 & 93 & 145 & 95 & 0.65 & $205 \pm 17$ & $115 \pm 10$ & 72 & 1,11 & 13,8 & - \\
\hline 4 & $\sigma^{\pi}$ & 48 & 38 & 117 & 140 & $?$ & 0.65 & $261 \pm 20$ & $136 \pm 11$ & 23 & $2, w 19,(w 32)$ & $12, \mathrm{w} 15$ & w3 \\
\hline 5 & $\sigma^{\pi}$ & 58 & 40 & 97 & 165 & 70 & 0.60 & $170 \pm 26$ & $101 \pm 23$ & 23 & $9,10,(w 25)$ & w 15,18 & w3 \\
\hline 6 & $0^{7}$ & 54 & 42 & 115 & 140 & 80 & 0.59 & $236 \pm 20$ & $128 \pm 9$ & 5 & 1,3 & w15, 8 & w3 \\
\hline 7 & $\sigma^{\prime \prime}$ & 43 & 42 & 90 & 140 & 85 & 0.37 & $384 \pm 37$ & $217 \pm 16$ & 21 & 1,9 & w16 & - \\
\hline 8 & 9 & 31 & 24 & 93 & 120 & 80 & 0.76 & $298 \pm 33$ & $164 \pm 23$ & 20 & $2,10,(w 25)$ & w15, 18 & w3 \\
\hline 9 & 9 & 45 & 21 & 100 & 120 & 80 & 0.33 & $270 \pm 32$ & $143 \pm 15$ & 27 & 2,9 & w15, 12 & w3 \\
\hline 10 & 9 & 53 & 32 & 99 & 130 & 80 & 0.56 & $370 \pm 23$ & $219 \pm 15$ & 38 & $2, w 32$ & $w 40$ & w3 \\
\hline 11 & 字 & 48 & 45 & 92 & 160 & 80 & 0.54 & $279 \pm 32$ & $176 \pm 21$ & 20 & 3 & w15, 7 & w3 \\
\hline 12 & 9 & 41 & 37 & 90 & 150 & 90 & 0.71 & $303 \pm 84$ & $170 \pm 32$ & 167 & 2,3 & $12, w 15$ & w3 \\
\hline 13 & $q$ & 59 & 30 & 86 & 140 & 90 & 0.46 & $458 \pm 29$ & $293 \pm 23$ & 66 & 2 & w15 & w3 \\
\hline 14 & 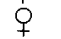 & 62 & 41 & 93 & 155 & 90 & 0.53 & $314 \pm 26$ & $181 \pm 18$ & 10 & 1,2 & w15, w35 & $w 3, w 4$ \\
\hline 15 & 9 & 35 & 30 & 95 & 120 & 85 & 0.46 & $214 \pm 25$ & $110 \pm 13$ & 35 & 9, w19 & $8,14,(w 16)$ & - \\
\hline Mean & & 47 & 33 & 98 & 141 & 84 & 0.58 & $278 \quad 29$ & 15916 & 36 & & & \\
\hline$\pm \mathrm{SEM}$ & & 2.7 & 2.2 & 2.8 & 3.6 & 2.1 & 0.054 & 21.24 .4 & 13.91 .8 & 10.7 & & & \\
\hline
\end{tabular}

(developed and employed by Siperstein et al. [9]) the basement membrane was measured in twenty equidistant places around the periphery of the vessel. In the other method (recommended by Williamson et al. [10]) the muscle capillary basement membrane was measured only at the two points where it was thinnest. These points were at least $0.5 \mu \mathrm{m}$ apart. All measurements were made without knowledge of the group the patients belonged to.

The following tests were used for statistical evaluation: correlation between age and basement membrane thickness, diabetes duration and basement membrane thickness by the rank correlation test of Kendall; differences between two means by the MannWhitney Wilcoxon rank sum test. For comparison of frequencies in two groups, Fisher's exact test was used.

\section{Results}

Individual data and results are listed on Table 1-3. Data of controls in Table 1 . Table 2 contains the data of diabetics with proliferative retinopathy and Table 3 the data of patients with no or minimal retinal changes. Age, \% ideal body weight and blood pressure were not significantly different between groups. Neither were there significant differencies in diabetes duration or insulin requirement between the two diabetic groups (Table 2 and 3). Haemoglobin was $8.7 \pm 0.53 \mathrm{mmol} / 1$ (mean $\pm \mathrm{SD}$ ) in controls, $8.8 \pm 0.93$ in diabetics with proliferative retinopathy and $8.8 \pm 0.74$ in diabetics without proliferative retinopathy. Serum creatinine was $83 \pm 11.7 \mu \mathrm{mol} / \mathrm{l}$,
$83 \pm 12.7$ and $86 \pm 13.1 \mu \mathrm{mol} / 1$, respectively. Serum cholesterol in the patients with proliferative retinopathy was $5.9 \pm 0.97 \mathrm{mmol} / 1$ and $5.7 \pm$ $0.92 \mathrm{mmol} / 1$ in the group without proliferative retinopathy (normal range $4.0-8.0 \mathrm{mmol} / 1$ ). Serum albumin in the two groups was $37 \pm 3.8$ and $36 \pm$ $2.9 \mathrm{~g} / 1$ respectively (normal range $31-42 \mathrm{~g} / \mathrm{l}$ ). Electrocardiography did not reveal signs of heart disease in any of the diabetics involved in the investigation.

\section{Muscle Capillary Basement Membrane Thickness}

Fig. 1 shows the thickness of muscle capillary basement membranes in diabetics and non-diabetics. The method of Siperstein et al. yielded an average basement membrane thickness which was about 1.7 times higher than Williamson's method. This ratio between the two techniques was similar in diabetics and in non-diabetics regardless of the thickness.

The diabetics had significantly $(p<0.001)$ thicker muscle capillary basement membrane than the nondiabetics ( $272 \pm 80$ vs $163 \pm 33 \mathrm{~nm}$ using the Siperstein method and $155 \pm 55$ vs $99 \pm 18 \mathrm{~nm}$ by Williamson's method). Only one non-diabetic had basement membranes thicker than $200 \mathrm{~nm}$ using the former method while 32 out of the 39 diabetics had basement membranes thicker than $200 \mathrm{~nm}$. No correlation was found between basement membrane 
Table 3. Clinical details and basement membrane thickness in diabetics with minimal changes. Individual data including muscle capillary basement membrane thickness measured with Siperstein's (a) and Williamson's (b) procedure, insulin-binding capacity of insulin antibodies (IBC) and HLA antigens on A, B and C locus in 24 insulin-dependent diabetics with no or minimal changes on the retina by ophthalmoscopy

\begin{tabular}{|c|c|c|c|c|c|c|c|c|c|c|c|c|c|}
\hline \multirow[t]{2}{*}{ No. } & \multirow[t]{2}{*}{ Sex } & \multirow[t]{2}{*}{$\begin{array}{l}\text { Age } \\
\text { (years }\end{array}$} & \multirow{2}{*}{$\begin{array}{l}\text { Dura- } \\
\text { tion } \\
\text { of dia- } \\
\text { betes } \\
\text { (years) }\end{array}$} & \multirow{2}{*}{$\begin{array}{l}\% \\
\text { ideal } \\
\text { body } \\
\text { weight }\end{array}$} & \multicolumn{2}{|c|}{$\begin{array}{l}\text { Blood pressure } \\
\text { mmHg }\end{array}$} & \multirow{2}{*}{$\begin{array}{l}\text { Ins. } \\
\text { req. } \\
(\mathrm{U} / \mathrm{kg})\end{array}$} & \multicolumn{2}{|c|}{$\begin{array}{l}\text { Basement mem- } \\
\text { brane thickness } \\
\text { mean } \pm S D(n m)\end{array}$} & \multirow[t]{2}{*}{$\begin{array}{l}\text { IBC } \\
(\mu \mathrm{U} / \mathrm{ml})\end{array}$} & \multicolumn{3}{|c|}{ HLA - antigens } \\
\hline & & & & & systolic & diastolic & & (a) & (b) & & A & B & $\mathrm{C}$ \\
\hline 1 & 0 & 36 & 24 & 108 & 145 & 80 & 0.68 & $246 \pm 27$ & $154 \pm 15$ & 13 & 1,2 & 8,12 & - \\
\hline 2 & $0^{x}$ & 53 & 24 & 91 & 135 & 90 & 0.43 & $233 \pm 17$ & $147 \pm 14$ & 20 & 2,3 & $8, w 15$ & w3 \\
\hline 3 & $0^{2}$ & 39 & 26 & 113 & 155 & 95 & 0.52 & $249 \pm 18$ & $137 \pm 8$ & 25 & 1,2 & $8, w 15$ & w3 \\
\hline 4 & $\sigma^{x}$ & 43 & 38 & 101 & 130 & 90 & 0.41 & $195 \pm 12$ & $109 \pm 9$ & 28 & 3, w24 & $7, w 15$ & w3 \\
\hline 5 & $\sigma^{\pi}$ & 51 & 37 & 105 & 110 & 70 & 0.57 & $289 \pm 20$ & $151 \pm 12$ & 15 & $\Rightarrow$ & $\because$ & 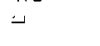 \\
\hline 6 & $\sigma^{7}$ & 61 & 39 & 107 & 120 & 75 & 0.29 & $325 \pm 48$ & $176 \pm 29$ & 4 & $11, w 25$ & 18 & - \\
\hline 7 & $\sigma^{7}$ & 54 & 34 & 91 & 140 & 85 & 0.31 & $208 \pm 15$ & $116 \pm 13$ & 19 & 1, w 26 & w22, w39 & w3 \\
\hline 8 & $0^{7}$ & 35 & 33 & 95 & 150 & 80 & 0.45 & $293 \pm 21$ & $168 \pm 14$ & 48 & 1,2 & 8, w15 & w3 \\
\hline 9 & $\sigma^{7}$ & 52 & 32 & 89 & 135 & 75 & 0.40 & $193 \pm 28$ & $108 \pm 14$ & 20 & $2, \mathrm{w} 30$ & 18, w15 & w3 \\
\hline 10 & $0^{7}$ & 46 & 26 & 102 & 135 & 90 & 0.71 & $263 \pm 16$ & $156 \pm 11$ & 1 & $=$ & 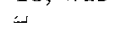 & - \\
\hline 11 & $0^{x}$ & 52 & 25 & 101 & 135 & 80 & 0.62 & $257 \pm 17$ & $154 \pm 11$ & 54 & 2 & $27, w 40$ & w2, w3 \\
\hline 12 & $\sigma^{\prime}$ & 46 & 23 & 92 & 140 & 80 & 0.47 & $221 \pm 22$ & $121 \pm 13$ & 40 & - & - & - \\
\hline 13 & $\sigma^{\prime \prime}$ & 59 & 35 & 98 & 140 & 85 & 0.80 & $216 \pm 18$ & $135 \pm 10$ & 297 & 1,11 & 8, w15 & w3 \\
\hline 14 & $\sigma$ & 21 & 20 & 92 & 130 & 85 & 0.65 & $401 \pm 29$ & $361 \pm 18$ & 10 & 2 & $\mathrm{w} 40, \mathrm{w} 15$ & w3 \\
\hline 15 & $\sigma^{\prime}$ & 54 & 52 & 117 & 140 & 85 & 0.43 & $493 \pm 46$ & - & 44 & 3 & 7,18 & - \\
\hline 16 & $q$ & 30 & 27 & 114 & 135 & 80 & 0.65 & $192 \pm 11$ & $105 \pm 5$ & & 1011 , w30 & 12,18 & - \\
\hline 17 & $\stackrel{+}{0}$ & 50 & 22 & 85 & 130 & 80 & 0.75 & $127 \pm 6$ & $84 \pm 9$ & 37 & 2,3 & $14, w 17$ & - \\
\hline 18 & O & 51 & 35 & 110 & 150 & 85 & 0.62 & $338 \pm 20$ & $207 \pm 20$ & 147 & $1, \mathrm{w} 25$ & 8,18 & - \\
\hline 19 & $\stackrel{+}{+}$ & 49 & 38 & 80 & 150 & 80 & 0.35 & $421 \pm 42$ & $230 \pm 48$ & 300 & 2, w19 & $12, w 15$ & w3 \\
\hline 20 & q & 55 & 36 & 86 & 150 & 90 & 0.22 & $194 \pm 25$ & $109 \pm 13$ & 12 & 2 & w15, w21 & w3 \\
\hline 21 & $q^{+}$ & 63 & 36 & 88 & 160 & 90 & 0.68 & $264 \pm 17$ & $135 \pm 13$ & 18 & w33, w32 & 18, w40 & w2 \\
\hline 22 & $\overrightarrow{0}$ & 42 & 33 & 109 & 140 & 80 & 0.73 & $239 \pm 14$ & $132 \pm 6$ & 39 & 2,28 & 8,12 & - \\
\hline 23 & q & 58 & 28 & 92 & 150 & 70 & 0.45 & $399 \pm 27$ & $212 \pm 18$ & 17 & 1, w24 & 8 & - \\
\hline 24 & $q$ & 54 & 41 & 84 & 160 & 80 & 0.48 & $259 \pm 22$ & $120 \pm 9$ & 278 & 1, w26 & 8, w15 & w3 \\
\hline Mean & & 48 & 32 & 98 & 140 & 83 & 0.53 & $269 \quad 21$ & $\begin{array}{ll}153 & 14\end{array}$ & 62 & & & \\
\hline$\pm \mathrm{SEM}$ & & 2.1 & 1.5 & 2.2 & 2.4 & 1.3 & 0.032 & 16.72 .0 & 12.11 .9 & 18.3 & & & \\
\hline
\end{tabular}

thickness and age, either among the diabetics or nondiabetis $(\mathrm{r}=0.02)$. The duration of diabetes $(20-52$ years) did not correlate with basement membrane thickness $(r=0.19)$. In patients with proliferative retinopathy the muscle capillary basement membranes was not thicker than in patients without retinopathy $(\mathrm{p}>0.05)$.

Insulin antibodies were found in 30 of the diabetics $(75 \%)$. No correlation was found between the insulin-binding capacity and basement membrane thickness $(r=0.20)$ and no difference in insulinbinding capacity was detected between patients with and without proliferative retinopathy. The thickness of basement membrane in patients with high insulinbinding capacity $(\geq 50 \mu \mathrm{U} / \mathrm{ml}$ ) was not significantly increased compared to patients with low insulinbinding capacity $(<50 \mu \mathrm{U} / \mathrm{ml})$. The results of the HLA-determinations are shown in Table 4 . The wellknown accumulation of HLA B8, B18 and Bw15 in insulin-dependent diabetics was confirmed as well as the decrease of B7 [13]. In patients with proliferative retinopathy only the HLA antigen Bw15 deviated significantly $(p<0.001)$ from the controls, but in the larger group without retinopathy $\mathrm{B} 7, \mathrm{~B} 18$ as well as Bw15 deviated significantly from non-diabetics. The difference of HLA - A9, B8, B18 and Bw40 antigens between patients with severe retinopathy and patients without retinopathy appeared considerable, but did not reach statistical significance on the 5 per cent level. No difference in basement membrane thickness was found between diabetics with or without tissue types B8 and/or Bw15 ( $p>0.05$ ). Seven of eight patients with high insulin-binding capacity ( $\geqslant 50 \mu \mathrm{U} / \mathrm{ml}$ ) had HLA B8 and/or Bw15, but high insulin-binding capacity ( $\triangleq 50 \mu \mathrm{U} / \mathrm{ml})$ was not statistically more frequent in diabetics with the tissue types HLA B8 and/or Bw15 ( $\mathrm{p}=0.3)$.

\section{Discussion}

The two morphometric methods for the estimation of basement membrane thickness have been compared among others by Beauchemin et al. [11], who by 


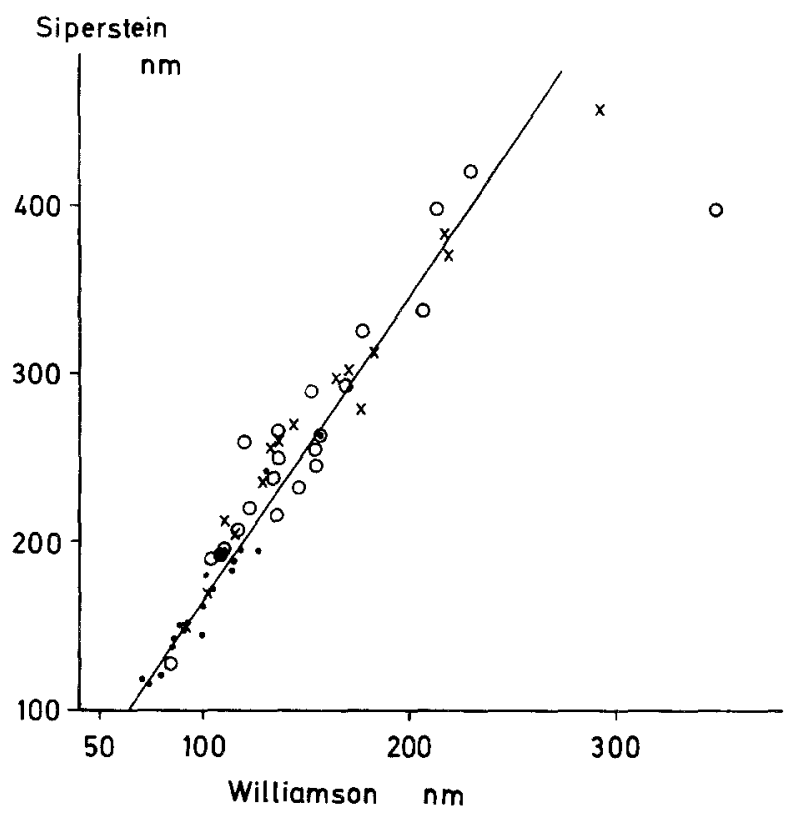

Fig. 1. Correlation of the thickness of the basement membrane of muscle capillaries measured according to Siperstein and Williamson. The biopsies were from 18 nondiabetics and 38 diabetics. - = non-diabetics $-0=$ diabetics with no or minimal changes by ophthalmoscopy $-x=$ diabetics with proliferative retinopathy

means of a nested variance analysis found Williamson's method to be the most precise. The comparison presented in this communication has shown the procedure of Siperstein to be more discriminating, since $82 \%$ of diabetics and only one non-diabetic had muscle capillary basement membrane thickness of $>200 \mathrm{~nm}$, whereas by Williamson's method only $74 \%$ of the diabetics and 2 non-diabetics had capillary basement membrane thickness of $\supseteq 120 \mathrm{~nm}$. It therefore seems reasonable to prefer Siperstein's method even if the method of Williamson is easier to perform and less time-consuming [9]. We have not however, used the fixation procedure of Williamson, but the method of Siperstein for both measurements.

It is assumed that the diabetic microangiopathy morphologically expressed as a thickening of the capillary basement membrane is caused by metabolic and hormonal disturbances due to the lack of endogenous insulin. The microangiopathy is assumed to lead to severe organ damage such as nephropathy and possibly plays a role in the development of retinopathy [14]. The present investigation shows, however, that the basement membranes of muscle capillaries may be of normal calibre even in patients who have had diabetes for more than 20 years and who have become blind from retinopathy. Furthermore the investigation shows, that the muscle capillary basement membranes in patients with proliferative retinopathy are not thicker than in diabetics with
Table 4. HLA typing in controls, diabetics with proliferative retinopathy and diabetics with minimal changes. No significant differencies were found between patients with and without proliferative retinopathy

\begin{tabular}{|c|c|c|c|c|}
\hline \multirow[b]{2}{*}{$\begin{array}{l}\text { HLA- } \\
\text { antigen }\end{array}$} & \multicolumn{4}{|c|}{ Tissue types frequency (per cent) } \\
\hline & $\begin{array}{l}\text { Controls } \\
(n=1967)\end{array}$ & $\begin{array}{l}\text { Non-proli- } \\
\text { ferative } \\
(\mathrm{n}=21)\end{array}$ & $\begin{array}{l}\text { Proli- } \\
\text { ferative } \\
(n=15)\end{array}$ & $\begin{array}{l}\text { Total } \\
\text { patients } \\
(n=36)\end{array}$ \\
\hline HLA-A 1 & 31.1 & 38.1 & 33.3 & 36.1 \\
\hline HLA-A 2 & 53.6 & 52.4 & 53.3 & 52.8 \\
\hline HLA-A 3 & 26.9 & 19.0 & 20.0 & 19.4 \\
\hline HLA-A 9 & 17.3 & 9.5 & 26.7 & 16.7 \\
\hline HLA-A10 & 9.6 & 19.0 & 13.3 & 16.7 \\
\hline HLA-A11 & 10.1 & 14.3 & 13.3 & 13.9 \\
\hline HLA-A28 & 10.0 & 4.8 & 6.7 & 5.6 \\
\hline HLA-Aw19 & 17.8 & 19.0 & 20.0 & 19.4 \\
\hline HLA-B 5 & 10.6 & 0.0 & 6.7 & 2,8 \\
\hline HLA-B 7 & 26.8 & 9.5 & 6.7 & 8.3 \\
\hline HLA-B 8 & 23.7 & 42.9 & 20.0 & 33.3 \\
\hline HLA-B12 & 25.2 & 19.0 & 26.7 & 22.2 \\
\hline HLA-B13 & 4.3 & 0.0 & 6.7 & 2.8 \\
\hline HLA-B14 & 4.5 & 4.8 & 6.7 & 5.6 \\
\hline HLA-B18 & 7.1 & 28.6 & 13.3 & 22.2 \\
\hline HLA-B27 & 8.6 & 4.8 & 6.7 & 5.6 \\
\hline HLA-Bw15 & 17.9 & 47.6 & 66.7 & 55.6 \\
\hline HLA-Bw16 & 5.4 & 4.8 & 6.7 & 5.6 \\
\hline HLA-Bw17 & 7.7 & 4.8 & 0.0 & 2.8 \\
\hline HLA-Bw21 & 3.5 & 4.8 & 0.0 & 2.8 \\
\hline HLA-Bw22 & 3.8 & 4.8 & 0.0 & 2.8 \\
\hline HLA-Bw35 & 13.1 & 0.0 & 6.7 & 2.8 \\
\hline HLA-Bw40 & 17.9 & 14.3 & 6.7 & 11.1 \\
\hline
\end{tabular}

One, two and three asterisks indicate significance at the 5, 1 and $0.1 \%$ level, respectively. Comparisons are made with the control group by means of Fisher's exact test

long duration of the disease but with no or minimal complications. If one assumes that muscle capillary basement membrane thickness reflects basement membrane thickness in the retina, these observations could be taken to indicate that muscle basement membrane thickness is not a useful index for monitoring deleterious effects of the diabetic state on the vascular system and that other factors should be considered responsible for the development of retinopathy.

The well-known increased frequencies of HLA $\mathrm{B} 8, \mathrm{~B} 15$ and B18, and the decreased frequency of B7 in insulin-dependent diabetes $[13,22]$ was also seen in the total group of patients in this study although the increase of B8 was not significant in this small sample. In fact B8 and A1 had a normal frequency in the group of patients with severe retinopathy which is in contrast to other independent studies $[15,16,17]$ which showed a higher frequency of $\mathrm{B} 8$ in patients with retinopathy compared to patients without retinopathy. In maturity-onset diabetes, Becker et al. [17] found an increased frequency of B8 in patients 
without retinopathy. Considering all available data, however, there is at present no evidence that HLA is involved in the susceptibility to retinopathy once insulin-dependent diabetes has developed. Accordingly, the genetic background for the development of this complication [18] probably involves non-HLA genes.

Seven of the eight patients with high insulin antibody titres (measured as insulin-binding capacity $\geqslant 50 \mu \mathrm{U} / \mathrm{ml}$ ) had HLA-antigens B8 and/or Bw15. This is in accordance with the findings of others [19]. However, the findings of Ortved Andersen [20], who found significantly increased basement membrane thickness in muscle capillaries of insulin-dependent diabetics with high insulin antibody titres, could not be confirmed in the present study.

Proliferative retinopathy seems not to be more frequent in heavy cigarette smokers ( 3 of 10 ) than in non-cigarette smokers (10 of 25) as it was the case in Paetkau's material [21], but our numbers were very small.

Further studies are needed to isolate factors of importance for the development of late diabetic complications.

Acknowledgement. For skilful help with determination of IBC, Basement Membrane measurements and HLA typing we want to thank Hanne Richter Olesen and Bodil K. Jacobsen.

Aided by grants from the Nordic Insulin Foundation, the Danish Medical Research Council, and the Danish Rheumatoid Association.

\section{References}

1. Williamson, J. R., Kilo, C.: Current status of capillary basement membrane disease in diabetes mellitus. Diabetes 26, 65-73 (1977)

2. Østerby, R.: Early phases in the development of diabetic glomeruloparthy. Acta Med. Scand. (Suppl.) 574, 1-80 (1975)

3. Thomsen, A. C.: The kidney in diabetes mellitus. Thesis, pp. 240-242. Copenhagen: Munksgaard 1965

4. Watkins, P. J., Blainey, J. D., Brewer, D. B., Fitzgerald, M. G., Malins, J. M., O'Sullivan, D. J., Pinto, J. A.: The natural history of diabetic renal disease. Q. J. Med. 164, 437-456 (1972)

5. Natvig, H.: Nye høide - vekttabeller for norske kvinner og menn. Oslo: Landsforeningen for kosthold og helse 1956

6. Andersen, O.O., Brunfeldt, K., Abildgård, F.: A method for quantitative determination of insulin antibodies in human plasma. Acta Endocrinol. (Kbh.) 69, 195-208 (1972)

7. Kissmeyer-Nielsen, F., Kjerbye, K. E.: Lymphocytotoxic microtechnique. Purification of lymphocytes by flotation. His- tocompatibility testing. Curtoni, E. S. V., Mattievz, P. L., Tosi, R. M (Eds.): pp. 381-383, Copenhagen: Munksgaard 1967

8. Nielsen, L. Staub, Jersild, C., Ryder, L. P., Svejgaard, A.: HLA antigen, gene, and haplotype frequencies in Denmark. Tissue Antigens 6, 70-76 (1975)

9. Siperstein, M.D., Unger, R. H., Madison, L. L.: Studies of muscle capillary basement membranes in normal subjects, diabetic and prediabetic patients. J. Clin. Invest, 47, 1973-1999 (1968)

10. Williamson, J. R., Vogler, N. J., Kilo, C.: Estimation of vascular basement membrane thickness. Diabetes 18, 567-578 (1969)

11. Beauchemin, M. L., Antille, G., Leuenberger, P. M.: Capillary basement membrane thickness: A comparison of two morphometric methods for its estimation. Microvasc. Res. 10, 76 (1975)

12. Andersen, O. O.: The immunogenic properties of highly purified insulin preparations. The clinical importance of insulin-binding antibodies. Acta Endocrinol. (Kbh.) 78, 723-735 (1975)

13. Nerup, J., Platz, P., Andersen, O. O., Christy, M., Lyngsøe, J., Poulsen, J. E., Ryder, L. P., Nielsen, L. S., Thomsen, M., Svejgaard, A.: HLA antigens and diabetes mellitus. Lancet 1974 II. $864-866$

14. Palmberg, P. F.: Diabetic retinopathy. Diabetes 26, 703-709 (1977)

15. Larkins, R. G., Martin, F. I. R., Tait, B. D.: HLA patterns and diabetic retinopathy. Br. Med. J. 1978 I, 1111

16. Möller, E., Persson, B., Sterky, G.: HLA phenotypes and diabetic retinopathy. Diabetologia 14, 155-158 (1978)

17. Becker, B., Shin, D. H., Burgess, D., Kilo, C., Miller, W. V.: Histocompatibility antigens and diabetic retinopathy. Diabetes 26, 997-999 (1977)

18. Pyke, D. A., Tattersall, R. B.: Diabetic retinopathy in identical twins. Diabetes 22, 613-618 (1973)

19. Bertrams, J., Jansen, F. K., Grüneklee, D., Reis, H. E., Drost, H., Beyer, J., Gries, F. A., Kuwert, E.: HLA-antigens and immunresponsiveness to insulin in insulin-dependent diabetes mellitus. Tissue Antigens 8, 13-17 (1976)

20. Andersen, O. O., Egeberg, J.: The clinical significance of insulin antibodies. Acta Paediatr. Scand. [Suppl.] 270, 63-68 (1977)

21. Paetkau, M.E., Boyd, T.A.S., Winship, B., Grace, M.: Cigarette smoking and diabetic retinopathy. Diabetes 26, 46-49 (1977)

22. Svejgaard, A., Ryder, L. P.: Associations between HLA and Disease - Notes on methodology and a report from the HLA and disease registry. In: HLA and disease. Dausset, J., Svejgaard, A. (Eds.), pp. 46-71. Copenhagen: Munksgaard 1977

Received: October 29, 1978,

and in revised form: April 30, 1979

Torsten Deckert

Steno Memorial Hospital

Niels Steensens Vej 2

DK-2820 Gentofte

Denmark 